\title{
Medical Research Council Manual Muscle Test Score, Lateral Rotation
}

National Cancer Institute

\section{Source}

National Cancer Institute. Medical Research Council Manual Muscle Test Score, Lateral

Rotation. NCl Thesaurus. Code C139232.

The numerical value that represents the result of a clinical assessment of muscle strength and function during lateral rotation that is based on the Medical Research Council Manual Muscle Test. (Medical Research Council. Aids to examination of the peripheral nervous system. Memorandum no. 45, superseding War Memorandum No. 7. London: Her Majesty's Stationary Office; 1976. doi:10.1016/0022-510X(77)90205-2). 